\title{
Bartolomé Mitre y Vicente Fidel López. El pensamiento historiográfico argentino en el siglo XIX*
}

Mauricio Tenorio $T$.

\begin{abstract}
Análisis del largo debate entre esos personajes de la vida argentina así como las diversas interpretaciones que ha recibido para, a partir de ello, intentar explicar la historiografía latinoamericana.
\end{abstract}

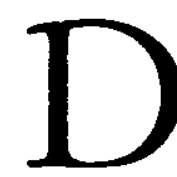

e lo que se han hecho las naciones, entre otras cosas, es de pasado lentamente reconstruido. En Hispanoamérica el siglo XIx fue siglo de construcciones nacionales, por tanto, espacio natural de "historias patrias". Los historiadores hispanoamericanos narraron su pasado inmediato no solamente para reposar su presente, sino, más importante, para adivinar y prever el futuro deseado. Empero, las historias patrias no se hacían en el vacío; unas fueron verdaderos manuales de ideas y preceptos político-sociales dictados por los modelos europeo y norteamericano; otras, como la de Burke, fueron "escritos revolucionarios" para evitar la revolución. Hasta la saciedad se ha escrito de la imitación, ideologización y burdo heroísmo de las historias patrias. El presente es un ensayo sobre historias patrias; específicamente, del hecho de pensarlas, de la búsqueda del cómoescribirlas en la Argentina del siglo XIX.

No sólo las borgianas "proas", que vinieron "por ese río de sueñera y barro", le fundaron la patria al poeta. Fue lento el proceso. En 1880 un multitudinario "mitin por la paz" tuvo lugar en Buenos Aires. Había que mantener la paz no obstante las divisiones políticas e ideo-

- Agradezco los comentarios y desacuerdos de Samuel Amaral a una versión preliminar de este ensayo. Toda responsabilidad es mía. 


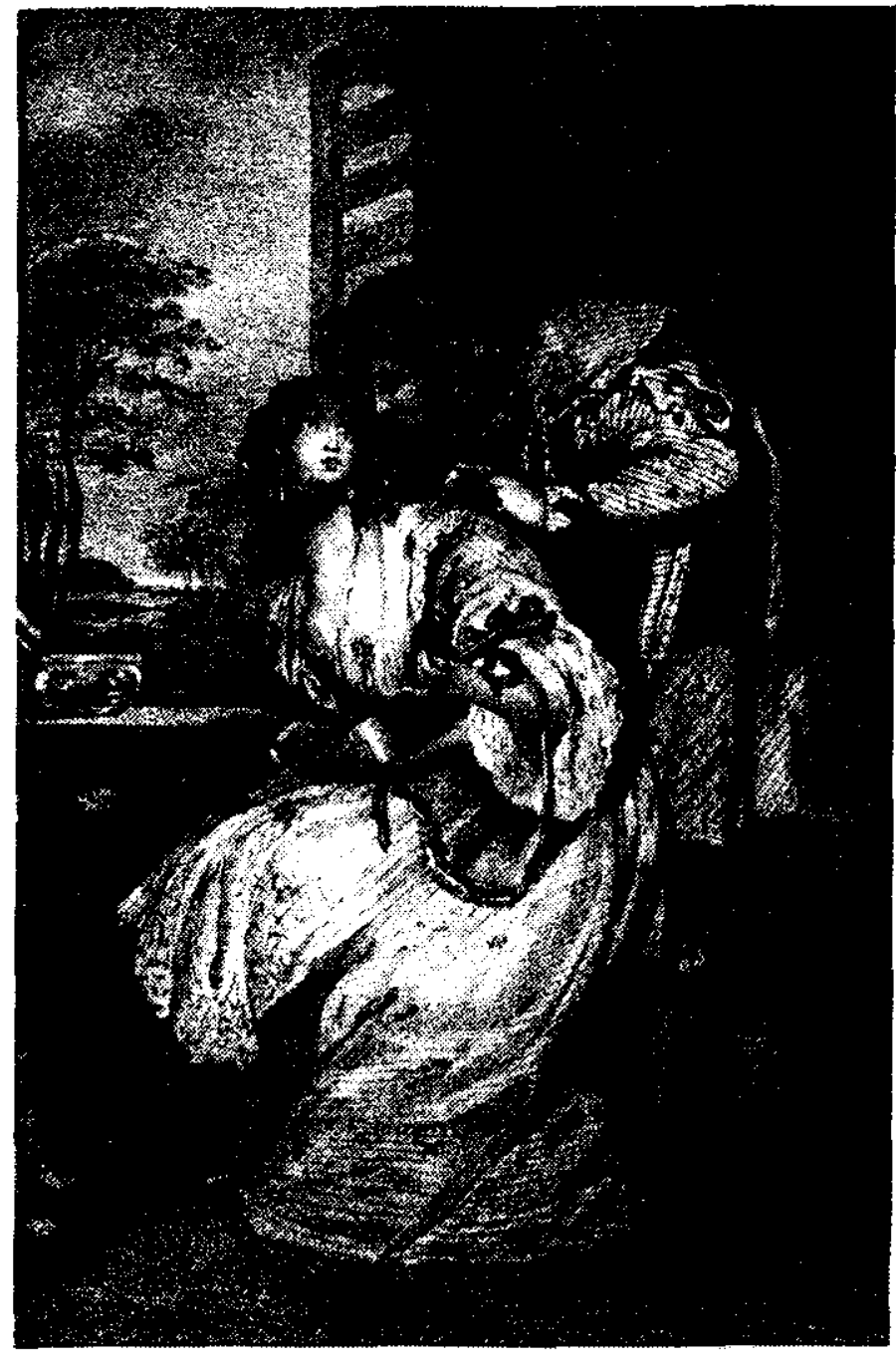

lógicas. Un año antes, el general Roca había exitosamente emprendido "la conquista del desierto". El ferrocarril ya cruzaba las pampas transportando materias primas para el comercio internacional; se iniciaban las inmigraciones que habrían de poblar esas pampas. Ese mismo año, 1879, José Hernández publica La vuelta de Martín Fierro. Así, para 1880 la consolidación territorial, la apreciación de la estabilidad política (o el hartazgo de la violencia) y la emergencia de una simbología de lo autóctono, ponían a las elites criollas del Río de la Plata más cerca del logro de lo preparado: la nación argentina. Pero la nación ya había sido prevista. Bartolomé Mitre y Vicente Fidel López, asistieron a aquel "mitin por la paz", como habían asistido durante casi todo el siglo XIX a la proyección y construcción de la nación pensada (uno con más actos, el otro con más prosa).

El ex presidente, general, historiador y poeta Bartolomé Mitre, en 1881 mantuvo un largo debate con el escritor y político Vicente Fidel López. Se trata de una autorreflexión de dos historiadores del siglo XIX, en sus propios términos, y desde su época. Un terreno más que fértil para examinar el pensamiento historiográfico del siglo XIX en Hispanoamérica, el cual a su vez es base de una tradición historiográfica cuya trascendencia e importancia históricas desconocemos. Sin embargo, este ensayo reconoce que no hay en esta clase de exámenes, conclusión final posible a la que hubiera que llegar. Se trata sólo de mostrar los variados aspectos y dimensiones (narrativa, intelectual y política) del pensamiento historiográfico del siglo XIX. En la primera parte se analiza y reconoce al debate y a sus protagonistas, para seguidamente (II) enfrentar las distintas maneras en que ha sido interpretado. Finalmente, este ensayo aventura una explicación que intenta ser un punto de vista sobre la historiografia latinoamericana del siglo XIX, y una sintética propuesta metodológica para la historia de la historia.

En 1881 Bartolomé Mitre (1821-1906) no es meramente un historiador, es la representación prototípica de un tipo de liberalismo moderado posrosista, es en verdad un punto de referencia obligado para una nueva generación de políticos e intelectuales que estaban surgiendo en Argentina. Es ya el esbozo de héroe que escribe historias de héroes (Belgrano, San Martín). Ante él, Vicente Fidel López (1815-1903) se revela un intelectual de modestas ambiciones políticas que para 
1881 ha pasado de su apego al "gobierno de la razón" a un tipo de despotismo whig con espíritu romántico. ${ }^{1}$ Mitre es el hombre de armas que en septiembre de 1852 entra a Buenos Aires al mando de las fuerzas opuestas a Urquiza; el que diez años más tarde es presidente constitucional de Argentina, y conductor de la guerra contra Paraguay; el traductor de Dante y Víctor Hugo. La de López, en cambio, es vida de aulas y salones literarios; periódicos (v. gr. El Progreso que dirige junto con Sarmiento) y ministerios (Educación en 1852) e instituciones financieras (Banco de la Provincia, 18791883).

Los dos autores vivieron el exilio a la manera de Esteban Echeverría para quien "no [había] cosa más triste que emigrar". Políticamente, sus caminos intermitentemente se cruzaron y se separaron. En sus inicios literarios y políticos, Mitre, como Sarmiento, se inspiró en la llamada generación de 1837 (de la cual formó parte López). A Mitre y a López los encontró el destino del mismo lado en su oposición a Rosas. Más importante, ambos fueron "caballeros" de la historia: López, primero con Introducción a la bistoria de la Repuiblica Argentina(185?), y posteriormente con Historia de la República Argentina. Su origen, su revolución y su desarrollo político hasta 1852 (1883-1893); Mitre con Historia de Belgrano y de la independencia argentina (1² ed. , 1859; $4^{2}$ y definitivas, 1887) y su Historia de San Martín y de la

'Véase Tulio Halperin, "Prólogo" a Proyecto y construcción de una nación (Angentina 18461880), Biblioteca Ayacucho, Caracas, 1980. emancipación americana (1887-1890). ${ }^{2}$ La producción histórica de Mitre, y el debate con Vicente Fidel López, "casi hasta ayer" fueron, como sostiene Tulio Halperin, "los términos de referencia frente a los cuales creyeron necesario definirse los historiadores argentinos" ${ }^{3}$

En 1875 Bartolomé Mitre escribe al chileno Diego Barros Arana -quien, en el ambiente chileno, con Historia general de Chile (1885-1902) semeja la función historiográfica de Mitre- anunciándole la próxima (tercera) edición de Historia de Belgrano. En esta carta, de historiador a historiador, Mitre de paso ataca a varios historiadores argentinos y chilenos, entre ellos a V. F. López. Mitre advierte a su colega chileno: "tomen con cautela estos escritos [los de López] porque su bagaje histórico es muy liviano". Para López esto inicia la batalla. Sin embargo, la discusión florece hasta 1881, año en que López publica Historia de la revolución en la cual, reforzando el esquema esbozado en Introducción a la bistoria, contradice algunas de las afirmaciones de la tercera edición de Historia de Belgrano. Mitre contraataca de inmediato en artículos publicados en Nueva Revista de Buenos Aires y en La

2 Para una bibliografía completa de López, consúltese la bibliografía incluida en el tomo I de Debate bistórico. Refutación a las comprobaciones bistóricas sobre la Historia de Belgrano, ed. de la Biblioteca Argentina, dirigida por Ricardo Rojas, Buenos Aires, 1921. Para una bibliografia completa de Mitre consúltese la introducción al tomo I de las obras completas de Mitre editadas por el $\mathrm{H}$. Congreso de la Nación Argentina, Buenos Aires, 1942. En adelante, todas las citas provienen de estas ediciones de las obras de López y Mitre.

3 Tulio Halperin, La bistoniografía: treinta años en busca de un rumbo, p. 830. 
Nación (periódico fundado por él). Esa respuesta acabó por convertirse en el libro Comprobaciones bistóricas a propósito de la Historia de Belgrano (1881). López contesta con tres volúmenes de Refutación a las comprobaciones bistóricas de la Historia de Belgrano (1882). Y Mitre no calla, publica un libro nuevo: Comprobaciones bistóricas a propósito de algunos puntos de bistoria angentina seguin nuevos documentos (1882). Así es: a los historiadores latinoamericanos del siglo XIX la vida les es escritura. A cada cambio de opinión se les van las mil, dos mil páginas de vida.

En el contexto latinoamericano, no era inédito este tipo de debate, menos aún en el europeo. En la Europa del siglo XIX, J. B. Bury y G. Trevelyan ${ }^{4}$ enfrentaron sus concepciones de la historia, y sintetizaron el encuentro en los extremos típicos: historia como ciencia vs. historia como arte. En la América hispánica, aunque todos los países contaron con sus hacedores discursivos de naciones, no existió un debate generalizado y potente del cómo escribir la historia de las naciones recién independizadas. Empero, en Chile (BelloLastarria en 1844-1848) ${ }^{5}$ antes que en

4 Véase de Bury "History as a science" y de Trevelyan "Clio, a muse" en Stern (comp.), The varieties of history. From Voltaire to the present, Londres, 1970.

'Consúltese A. Woll, A functional past. The uses of history in nineteenth century Cbile, Londres, 1982, y G. Colmenares, Las convenciones contra la culiura, Bogotá, 1987, especialmente el capítulo I. Woll explica las distintas discusiones historiográficas que tuvieron lugar en el Chile del siglo xix, de acuerdo a los distintos proyectos políticos. Colmenares pone el debate Bello-Lastarria en el contexto de la historiografia del cono sur durante el siglo $\mathrm{xIX}$.
Argentina (Mitre-López), se dio un debate a este respecto de proporciones más o menos significativas.

No obstante lo largo y detallado del debate de Mitre y López, la esencia de la discordia, aparentemente, radica en dos entendimientos distintos del "oficio de historiador". En tanto para Mitre en Historia de Belgrano "...no se indica un sólo gesto, ni se avanza una sola opinión que no pudiese ser documentada... ${ }^{n 6}$, para López:

...los altos fines de la historia moderna deben desenvolverse y exhibirse con tendencias filosóficas; que los hechos que constituyen la historia de una nación deben presentarse con todo el color y la fisonomía de la época en que sucedieron; que las costumbres y los hábitos de un pueblo, las ideas de un tiempo y el progreso moral de un periodo histórico, deben entrar en el análisis del escritor como elemento fundamental y esencialísimo de su misión en las letras...la historia y la filosofia de la historia marchan juntas, y el autor que rechazara de su método histórico las tendencias filosóficas no podría, en nuestra opinión, reclamar con justicia otro lugar entre los autores modernos que el de los compiladores pacientes o incoloros de la cronologia. $^{7}$

Alrededor de esta contradicción fundamental, Mitre y López se enfrascan en un sinnúmero de desacuerdos en fechas $-v . g r .1740$ (López) vs. 1748 (Mitre) como fecha del inicio de la reforma que daba permiso para que "los buques de registro viniesen directamente a Buenos Aires $"-,{ }^{8}$ colorido de los héroes -Alzaga

\footnotetext{
6 Mitre, Comprobaciones, p. 18.

' López. Debate bistórico, t. I, p. 84.

lbid, t. I, pp. 150-153.
} 
como héroe (Mitre) o farsante (López) de la defensa de Buenos Aires-, geografia de los lugares, posición y número de los objetos en la historia....

A lo largo del debate, López no sólo intenta probar la superioridad de su método "filosófico", sino que pretende demostrar que el mismo Mitre hace uso de éste para ordenar su centenar de datos. Incluso, en el capítulo cuatro del tomo I de Debate bistórico, a contracolumnas López contrasta su Introducción a la bistoria con la tercera edición de la Historia de Belgrano con el objeto de demostrar que Mitre se inspiró en su trabajo (al añadir el capítulo sobre "la sociabilidad argentina"). López afirma:

Su sistema histórico de documentación [de Mitre] no contenía la "fórmula" de la revolución, y le pareció que no había inconvenienteen prescindir completamente de él y de sus cien mil documentos, para encontrar la fórmula de mayo en el libro "escrito con las tendencias filosóficas y las ideas preconcebidas", que "debía tomarse con cautela", según sentencias de excomunión. ${ }^{9}$

Del total de la discusión entre Mitre y López, retomo dos momentos ejemplares que ilustran los tonos y matices del enfrentamiento. El primer ejemplo toca el tema del detalle de la geografía y monto de los objetos históricos; se refiere a la batalla por la defensa de Buenos Aires entre el ejército inglés y los criollos sublevados del virreinato del Río de la Plata. En su interpretación de este hecho, López toma apoyo en los Apuntamientos de Gregorio, el deán Funes ${ }^{10}$ en

- Ibid, p. 105.

to Véase Biografía, en Archivo del deán Gregorio Funes, Buenos Aires, 1944, vol. t. Cfr. Tulio periódicos, en narraciones de la época y en relatos orales fundamentalmente de su padre "quien todo esto nos había trasmitido". " López sostiene que en la defensa de Buenos Aires los soldados en la plaza de Santo Domingo "se echaron a las calles con cañones para derribar las puertas del templon. Por el contrario, Mitre, apoyado en "un expediente auténtico que tenemos a la vista" (citado por Mitre como: Testimonio de los senvicios contraídos por el coronel don José de Fornaquera, M.S. aut.), mantiene que no fueron "cañones" sino un cañón y un obús, dirigido a la torre y no a las puertas del templo.

Para el lector, el efecto producido por el "que tenemos a la vista" es de autenticidad y contundencia. Mitre, así, hace más vívido su apego a los documentos y a la "verdad" histórica: aparece inapelable. Por su parte López, fiel a su posición estilístico-filosófica, no duda en sostener que:

A nuestro juicio y al de todos los que comprenden la faz literaria de un trabajo histórico, basta, en los momentos de acción violenta y tumultuaria, trazar y animar el gran perfil de los sucesos con rasgos hondos que actúen el gesto y la fisonomía de conjunto... pues para la historia del detalle bastaría un notario minucioso o un empleado práctico. ${ }^{12}$

El tamaño y brillo de los héroes es el tema del segundo ejemplo. En 1807, en la defensa de Buenos Aires, Martín de

Halperin, "El letrado colonial como intelectual revolucionario: El deán Funes a través de sus apuntamientos para una biografia", Anwario, núm. $11,1988$.

"Lopez, Debate bistórico, t. 1, p. 63.

12 Ibid., t. I, p. 32. 
Alzaga miembro del cabildo de Buenos Aires, "alcalde de primer voto", parece haber sustentado momentáneamente la defensa de la ciudad ante los ingleses, en el momento en que Liniers, el héroe de la reconquista argentina de Buenos Aires, había sufrido una derrota en Miserere. ¿Cómo actuó Alzaga en este pequeño tramo de historia? Mitre y López tienen distintas respuestas. En este punto, los datos disponibles, la historia oral y la "tradición", sostiene Mitre, coinciden en que Alzaga cumplió "el primer papel en la noche triste del 2 de julio de 1807 , que fue el momento crítico de la defensa, y nadie ha negado que a su influencia se debió poner la condición de la entrega de Montevideo por los ingleses en las capitulaciones que siguieron". ${ }^{13}$

López es, descaradamente, hombre de letras, buscador de personajes; a él sencillamente le antipatiza el personaje de Alzaga, no le merece la toga de héroe: "Alzaga ni venció, ni organizó las tropas que vencieron, ni les dio el espíritu ni la pasión bélica de que estaban animadas, ni tampoco es cierto que fuera él quien retemplara el ánimo caído de los defensores." 14 En realidad, sostiene López, Mitre carece de criterio para juzgar toda la documentación que lo lleva a alabar a Alzaga:

Él no cuenta para nada con las pasiones de los hombres ni con las divergencias naturales de los habitantes de un pueblo agitado; prescinde de lo que es elemental en la vida humana; toma mecánicamente los documentos con que se encuentra, y

13 Mirre, Comprobaciones, p. 118.

${ }^{14}$ López, Debate bistórico, p. 9 (cita de su miroducción a la bistoria de la revolución argentina, pp. 189 y 190). recoge de ellos los datos que contienen sin someterlos a ningún género de análisis...para nuestro crítico la historia es un armario de mariposas embalsamadas, clavadas en sus tabletas, destinadas a exhibir momias y no hombres vivos animados de todas las pasiones que imperan en el espíritu humano. ${ }^{15}$

A Mitre, sin embargo, Alzaga le es igualmente antipático. Lo considera "espíritu reacio, rebelde al progreso económico y político del país...una alma dura, soberbia ${ }^{n} .{ }^{16}$ Empero, Mitre reconoce en Alzaga una atinada participación en la defensa de Buenos Aires y, por tanto, una razón para tenerlo en el pedestal de los héroes. La verdad histórica hace, pues, a los héroes, y no las simpatías del historiador. López acepta el papel "oficial" jugado por Alzaga pero niega que Alzaga "fuese un héroe legendario de aquella nochen de 1807 . Así, por tres largos capítulos Mitre desmiente lo que López llamó "la leyenda de Alzaga"; saca a luz documentos, testimonios y hasta la poesía épica de la época. Con otros no menos largos tres capítulos, López vuelve a responder a Mitre en el tono antes mencionado.

A lo largo de todo el debate, las "manzanas de discordia" siguen las líneas esbozadas en los ejemplos anteriores. Cualquier tema es poco para disentir: se discute por el mal uso de términos latinos, por la ortografía de los nombres británicos (Aschmuty vs. Auchmuty), por errores en las denominaciones monetarias, por variaciones en los cálculos de la población de Buenos Aires en 1810 (Mitre: 40 000; López: 70 000), por dife-

\footnotetext{
15 lbid., t. Il, pp. 12-13.

${ }^{16}$ Mitre, Comprobaciones, p. 119.
} 
rencias en la iogística bélica en la defensa de Buenos Aires, etcétera.

En cada tema parece repetirse la oposición central entre un Mitre partidario de la historia erudita y exhaustiva, cuyo objetivo final es la nación argentina, y un López partidario de una historia literaria, con una concepción filosófica del camino de los acontecimientos y cuyo fin es el momento histórico-heroico que es per se narrado, así como sus potencialidades épicas para dejar muestras del desarrollo de la nación.

\section{II}

Este debate ha sido un lugar común dentro de la historiografia argentina. Generalmente, ha sido interpretado como un eco de las discusiones de las "grandes" tendencias europeas filosóficohistóricas. La discusión Mitre-López se vuelve así cuestión de índice de autores (que Guizot, Tocqueville, Michelet, Boussuet, Herder,...). De esta manera, en el panorama hispanoamericano, el debate se inserta ya sea en la pugna entre el liberalismo francófilo, republicano contra el conservadurismo hispanófilo monárquico, o en la categoría de "historia patria", historia ideológica, esto es, no científica. Cuestión de tomar partido: ola historiografia "científica" (Mitre), o la historiografía literaria cuando mucho precientífica, si no es que anticientífica (López). Y es con frecuencia Mitre quien es considerado el puente, la clave o el pionero del desarrollo de la disciplina (científica) de la historia en Argentina. ${ }^{17}$

17 Véase sobre todo Rómulo D. Cabria, Historia critica de la bistoriografia argentina (desde sus
Esta visión enfatiza un hecho indudable: Mitre constituye un pilar de la historiografia argentina contemporánea, en tanto que López ha sido un tanto dejado en el olvido de la indiferencia. Empero, este criterio hace evidentes sus limitaciones al enarbolar el triunfo de una "manera" de hacer la historia (científica) sobre otra, cuando no desecha por completo la importancia tanto de las historias escritas por Mitre y López, como de su debate, por ser historias "ideológicas”, no científicas. En las sutilezas que

origenes en el siglo xv), La Plata, 1939, pp. 141-143; Joseph R. Barager, "The historiography of the Rio de la Plata area since 1830", Hispanic American Historical Review, núm. 4, 1959. Sin pretender que Mitre fuera un "científico de la historia" tout court, José Luis Romero también puede ser ubicado dentro de esta interpretación típica del debate Mitre-López, "Vicente Fidel López y la idea del desarrollo universal de la historia" y "Mitre un historiador frente al destino nacional", ambos en Argentina, imágenes y perspectituas, Buenos Aires, 1956. Robinson, Bartolome Mitre. Historian of the Americas, University Press of America, 1982, reproduce la interpretación típica del debate MitreLópez. Campobasi, Mitre y su época, EUDEBa, Buenos Aires, 1980 , aunque con una visión más consensual del debate, también ve a Mitre como el triunfo de la historiografia científica, del racionalismo sobre el irracionalismo. Botana, "Mitre y la historia de la libertad", La Nación, 1987 y en "Mitre y la historia de la independencia", La Nación, 1988, sin analizar especificamente el debate Mitre-López, y dentro de la más pura tradición de la historia del desarrollo de las ideas políticas liberales, proporciona interesantes variaciones de la interpretación clásica, especialmente al comparar los escritos de Mitre con la Histoire du dix-neuviéme siecle. Depuis les traités de Vienne, traducción francesa del libro del historiador alemán Gervinus, contemporáneo de Mitre. Una interpretación distinta pero aún más simplista se encuentra en Alberto Pla, Ideología y método en la bistoriografía argentina, Buenos Aires, 1972. Para Pla, Mitre y López se encuentran en la categoria de historiadores tradicionales: no contemplan los aportes del materialismo histórico, única forma científica de historia, según Pla. 


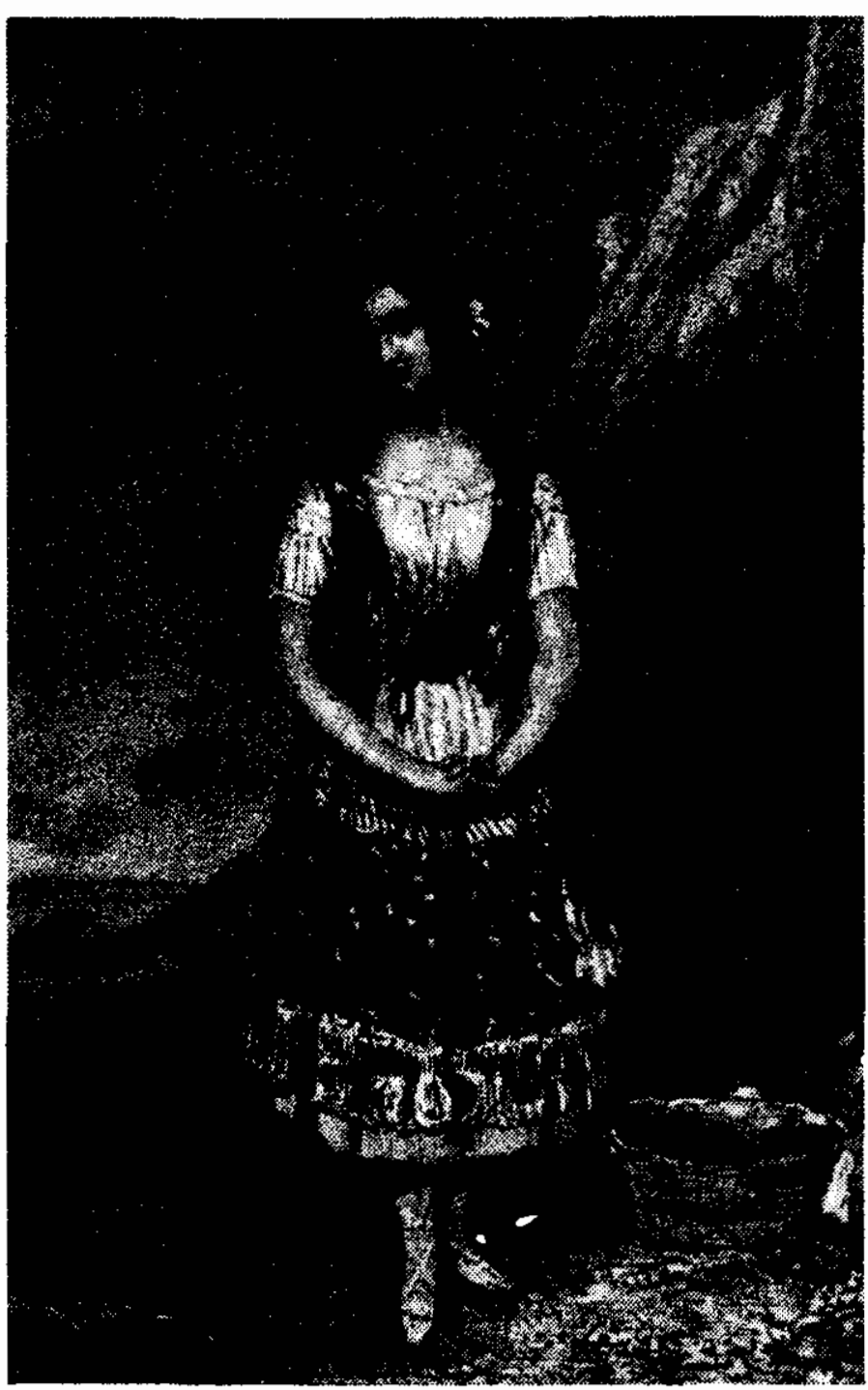

estas exageraciones ocultan, yacen las características del cómo se pensó la historia en el siglo XIX; características que no sólo determinaron la forma de las historias patrias, sino de los discursos de identidad, educación y cultura nacional.

Tulio Halperin, por una parte, y Germán Colmenares, por otra, presentan dos diferentes pero más penetrantes interpretaciones del debate Mitre-Lopez. ${ }^{18}$ En Halperin, su más aguda visión deriva de una perspectiva basada no en una aproximación a la historia de las ideas filosóficas, sino en la considera-

$10 \mathrm{~T}$. Halperin, La bistoriografía: treinta años de brisqueda de un rumbo; y Halperin, "Prólogo", Proyecto y construcción; G. Colmenares, Las convenciones contra la cultura, Bogotá, 1987. ción del debate en un panorama histórico harto abarcante (factores políticos, intelectuales, sociales...). Esto es, Halperin no toma la historiografia "científica" contemporánea como la visión triunfadora, o como la evolución final de la historiografía argentina (visión a la cual habría que buscarle antecedentes). Por el contrario, Halperin elabora la historia de un debate y sus consecuencias, y a través de esto concluye la no linealidad, las idas y retrocesos en el "hacer" de la historia en la Argentina. Proceso, para Halperin, inseparable de otro accidentado, complejo, a veces típico, a veces atípico de creación de la nación y del Estado.

Colmenares, por su parte, debe su agudeza a dos fuentes que lo nutren: la consideración del debate en la perspectiva general de la historiografía latinoamericana del siglo XIX (especialmente el cono sur), y al uso de recientes estudios teóricos de la historia. ${ }^{19}$

El historiador argentino José Luis Romero sostenía que el papel desempeñado por Mitre fue el de marcar "la línea de coherencia de nuestro pasado, proporcionar una conciencia clara de presente y fundamentar en una clara conceptualización de las ideas que informaban el desarrollo histórico, una

${ }^{19}$ En especial, los estudios de Barthes, El grado cero de la escritura, Siglo XXI, México, 1985, y su ensayo "Le discourse de l'histoire", Poétique, 49, febrero de 1982; Auerbach, Mimesis. The representation of reality in western literature, Princeton, 1968, y los estudios historiograficos sobre el siglo xIx europeo de Bann, The clothing of Clio: $A$ study of the representation of bistory in nineteenth century Britain and France, Cambridge, 1984, y White, Metabistory. The bistorical imagination in nineteenth century Europe, Nueva York, 1980. 
política postulada para el futuro" ${ }^{20}$ En efecto, ver a Mitre moviéndose en tres planos (pasado, presente y futuro) con un objetivo claro (la nación) es el punto de partida de las exitosas historias de las ideas.

Tulio Halperin también considera que Mitre da cuenta del pasado, presente y futuro a través de su concentración en el origen de la nacionalidad argentina, y por su forma de hacerlo lleva a la historiografía argentina a una "súbita madurez". Como político, diría Halperin, Mitre tuvo objetivos más pragmáticos: la creación del partido, del Estado que el rosismo nos legara. El liberalismo argentino del siglo XIX aunque políticamente presentó varias posiciones ( $v . g r$. federalistas $v s$. autonomistas), en su discurso historiográfico, contra lo que se cree, mostró gran homogeneidad. Tenía que ser así, la historia se escribía por ideales, y entre los historiadores argentinos del siglo XIX no hubo grandes variaciones en ideales. Lo que separa a Mitre y López no son ni fundamentalmente distintas concepciones de la labor del historiador, ni distintas lecturas filosóficas. En opinión de Halperin se trata de distintos alcances de visión.

En tanto López se regodea en el momento histórico y su heroísmo, Mitre arma distintos momentos heroicos en la construcción de una historia más complicada, a saber, la nación republicana. La manera en que Mitre escribía la historia, quedó definida por Halperin en su Revolución y guerra (1972) como la "participación en la construcción de un futuro que todos ignoran $y$ todos

${ }^{20}$ Romero, op. cit., p. 122, cursivas nuestras. preparan, y que ofrece la perspectiva desde la cual su postrero historiador los contempla y juzgan. ${ }^{21}$

López, en opinión de Halperin, está más interesado en el momento en que la burguesía porteña crea la república como "obra maestra de virtud política". Así, los objetivos de López tienen un más corto alcance: buscar el alma, la guía psicológico-arústica de los individuos en el regodeo del momento histórico, rescatar las narraciones y leyendas orales de los actores de la revolución de independencia, y sustentar con los datos necesarios el argumento de una historia ya aprendida y difundida.

Para Halperin, López no ve en la historia un resultado final valioso que dirija su pluma más allá del momento heroico per se. Mitre, en cambio, encuentra en el desarrollo de la "democracia inorgánica" nacional una guía omniordenadora de su narración histórica. La nación es el resultado del complejo proceso histórico en donde las elites, desbordadas por la coyuntura de la invasión inglesa, acaban por lograr su emancipación del antiguo régimen. Más importante, Halperin subraya en Mitre la existencia de ese juego de fuerzas contradictorias que ciegamente llevan al destino sabido: hasta 1820 la revolución es, para Mitre, un sí y un no del antiguo régimen, pero ante los caudillos que claudican, los héroes del Río de la Plata alcanzan la "democracia inorgánica". Este logro es señal inequívoca del camino natural del pasado (historia) en el pre-

\footnotetext{
${ }^{21}$ T. Halperin, Revolución y guerra. Formación de una elite dirigente en la Argentina criolla, Buenos Aires, 1982, p. 7.
} 


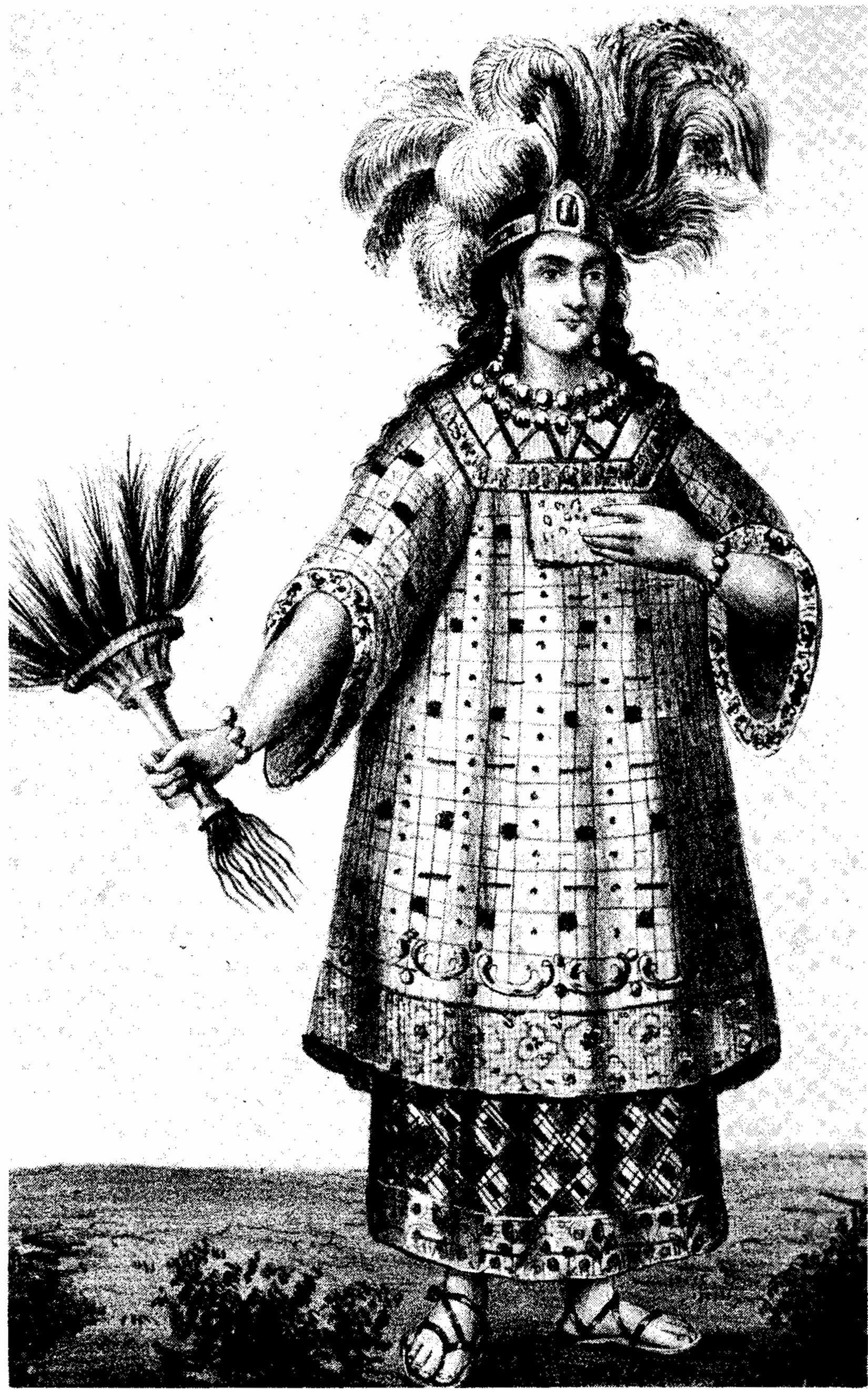


sente (desde donde se interpretaba) y agenda para el futuro (acabar de completar la democracia). Organizar esa democracia inorgánica, para Mitre era, sostiene Halperin, "una tarea todavía no acabada".22

Para este autor, pues, de hecho Mitre no se opone, sino que contiene a López:

La imagen de Mitre sobre el nacimiento de la nacionalidad, no sólo integra los distintos planos de la realidad histórica -entre ellos los ignorados, o evocados sólo ocasionalmente por López- en un proceso unificado en torno al ético-político: en éste es capaz de mostrar el surgimiento de la nacionalidad no como la herencia constantemente amenazada de una de las corrientes en liza, sino como el fruto de la acción de todas las que a través de sus choques cooperan en ese resultado que por otra parte las excede. ${ }^{23}$

No es que Mitre no posea, a priori, un plano de la historia, no es que escriba la historia "científica basada en los datos", sino que en realidad el modelo que Mitre sigue para escribir la historia es de alcances mucho más amplios y, sobre todo, es mucho más afortunada su armonía entre los datos y su modelo. $Y$ eso, para Halperin, fue lo que hizo de Mitre un modelo a seguir en la historiografia argentina. Modelo que no encontrará paralelo, de acuerdo con Halperin, hasta bien entrado el siglo Xx.

El "paradigma" proporcionado por Mitre, sin embargo, entró en seria crisis, no puramente teórica, sino fundamentalmente política. Después de 1880, dice Halperin, la "democracia orgánica" (in-

\footnotetext{
${ }^{22}$ T. Halperin, La historiografía..., p. 831.

${ }^{23}$ lbid., p. 832.
}

trinseca a la nacionalidad argentina) se enfrenta ya no a las "tormentas en el camino pasado" sino a un statu quo que hacen las tormentas de la "democracia orgánica" convirtiendo al ideal de ésta en inalcanzable; se tiene la imitación y la forma perfecta, por lo que obtener el original y la esencia se vuelve casi imposible. ${ }^{24}$ Mitre había optado por un liberalismo que "no se limita a ofrecer una alternativa preferible a la conservadora o radical; recoge en sí mismo todas las notas válidas en ambas posiciones extremas, y al hacerlo despoja a ambas de cualquier validez". ${ }^{25}$ Para 1880 , el liberalismo de Mitre, tanto en política como en historiografia, enfrentan una crisis. Halperin la define:

Esa Argentina de 1880, que no está segura de haber concluido victoriosamente la navegación que debía dejar como herencia un país nuevo, comienza a adivinar que pronto ha de emprender otra. En el transfondo de esos exámenes sin complacencia de la república posible, empieza a discernirse una de las preguntas centrales de la etapa que va a abrirse: si es de veras posible la república verdadera, la que debe ser capaz de ofrecer a la vez libertad e igualdad, y ponerlas en la base de una fórmula política eficaz y duradera. ${ }^{26}$

${ }^{24} \mathrm{Ch}$. Hale pone este argumento en una perspectiva más general: en Argentina, México, Chile y Brasil "political peace was quickly restored...facilitated by a fundamental agreement in economic and social values. The PAN remained a power in Argentina until 1916. Díaz in Mexico until 1911. The chilenian parliament continued supreme until 1924. The constitutional 'balance' established in Brazil by 1894 prevailed until 1930", Hale, "Political and social ideas in Latin America, 1870-1930", en Cambridge History of Latin America, vol. Iv, p. 345.

${ }^{25}$ Halperin, "Prólogo", p. XLIX.

${ }^{26} \mathrm{lbid}$., p. $\mathrm{Cl}$. 
López, ante la crisis, acabó en la melancolía despótica: ante el fracaso del espíritu democrático, de que las masas sean dirigidas por los hombres de ideas. En historiografia, sin embargo, un nuevo modelo se hacía necesario. En esto parecen coincidir todas las historias de las ideas y los ensayos sobre la historiografia argentina. Para autores como Barager, Mitre "fue el primer nativo del área del Río de la Plata merecedor del titulo de historiador". ${ }^{27}$ Empero, para Barager, no es hasta la segunda década del siglo $\mathrm{XX}$ que se logra la verdadera historia objetiva y profesional. Los trabajos, primero de la llamada Nueva Escuela (autores como Louis L. Domínguez, Clemente L. Fregeiro, Paul Groussac), y finalmente de Ravignani y levene ${ }^{28}$ por fin llevaron, arguye Barager, a la historiografía argentina a un estado científico, maduro y objetivo.

La interpretación de Halperin, sin embargo, rebasa este argumento. Para Halperin, el logro de un "paradigma" más allá de Mitre, pero gracias a Mitre, estuvo fuera del alcance de la historiografía argentina hasta los años cuarenta. Halperin no tiene la confianza que Barager en esa Nueva Escuela de principios de siglo, la cual, dice Halperin, buscó refugio en "una estricta (o quizá estrecha) visión del trabajo histórico que pone en primer plano la recolección y crítica de materiales, y-para eludir mejor la tentación del escepticismo- deposita una maciza confianza en las algo pedestres recetas para hacer historia con-

${ }^{27}$ J.R. Barager, op. cit, p. 591.

28 E. Ravignani, Historia constitucional de la Repüblica Argentina, 1926; R. Levene, Lecciones de bistoria argentina, La Plata, 1913. tenidas en el manual de Bernheim". ${ }^{29}$ Mitre, pues, no está exactamente atrás de, por ejemplo, Groussac, sino que la historiografia argentina, como el camino de su construcción nacional, ha mostrado tropos y discontinuidades.

Germán Colmenares, por otra parte, saca al debate Mitre-López de su ambiente puramente argentino y lo proyecta en una dimensión latinoamericana. Para Colmenares, la inteligencia del cono sur americano en el siglo XIX estaba irremediablemente relacionada: Mitre que se escribía con intelectuales chilenos y había compartido cárcel con Benjamín Vicuña Mackenna, el chileno Diego Barros Arana que le mandaba a Mitre las obras del colombiano José Manuel Restrepo; Restrepo que leía al venezolano Rafael María Baralt; el peruano Paz Solán que citaba a Mitre; el ecuatoriano Federico González Suárez que estaba al día con los escritos de Barros Arana... ${ }^{30}$ Todos con un solo gran tema guiador, la independencia y la construcción de la nación: "su misión no era una mera labor académica que consistiera en ampliar un campo discursivo, sino la piadosa tarea del guardián del cuerpo de creencias comunes" ${ }^{31}$

Para Colmenares, el debate entre Mitre y López corea las creencias prevalecientes en la historiografía del siglo XIX. Ésta consideraba que sólo los documentos proporcionaban loselementos para crear lo que Colmenares llama "continuidad narrativa" (que sigue el orden cronológico de lo "real"). En este sentido historio-

\footnotetext{
${ }^{29}$ T. Halperin, La bistoriografia..., p. 840.

30 Véase Colmenares, Las convenciones, pp. $40-47$.
} 
gráfico de Colmenares, podría agregarse que los historiadores hispanoamericanos del siglo XIX podían disentir en cuáles y cuántos documentos debían sustentar la historia ( $v . g r$. Mitre-López), pero no en el valor de los documentos. López buscaba en los hechos los elementos humanos y emocionales (que abiertamente y de antemano sospechaba); para Mitre "hasta las emociones había que documentar". Para López, la riqueza de una interpretación estaba determinada por la coherente posición filosófica dentro de una lucha política global; para Mitre, aparentemente, es en la riqueza documental donde habita la perennidad de la obra histórica. Colmenares, sin embargo, no duda: Mitre también parte de un esquema que ordena sus documentos. En efecto, la riqueza de la interpretación de Colmenares está en sus sugerencias sobre el aspecto narrativo de las historias patrias. Como en una novela, la vida del héroe y de la nación se hacen una. ${ }^{32} \mathrm{El}$ héroe y el logro de la república, eso que Halperin llamaba el destino que nadie conoce pero que todos construyen, constituye el principio ordenador. Así pues, en opinión de Colmenares, Mitre y López son más similares de lo que a primera vista parecen; las objeciones de uno a otro muestran sus mutuas limitaciones. Como en el debate de los años de 1840 entre Bello-Lastarria en Chile, el origen de la discordia no está en meras

31 lbid., p. 22.

32 Al respecto consúltese B.E. Burns, "Bartolome Mitre: the historian as novelist, the novel as history", Revista Interamericana de Bibliografía, vol. 32, num. 2, pp. 155-167. Burns se centra en la novela de juventud de Mitre, Soledad (1847), para explicar, en Mitre, la concepción de la historia como una trama novelesca. diferencias ideológicas, sino que provenía "en gran parte de la incapacidad de reproducirlo [el pasadol de algún modo. Los contenidos culturales de ese pasado [el latinoamericano], fueran hispánicos o indígenas, escapaban a las formas de representación importadas de Europa" ${ }^{n 3}$ Tampoco Mitre se vio exento de eso que López llamaba "espíritu filosófico":ILa lectura de Mitre] convence rápidamente de que la infinidad de documentos que el autor gustaba de exhibir era más bien un pretexto para su imaginación...Mitre iba inscribiendo acontecimientos y personajes en una trama de significaciones de las que únicamente él podía tener el secreto, de 'leyes' que por alguna misteriosa razón sólo él conocía". ${ }^{34}$

El modelo liberal es el que, aunque de distinta forma, ambos historiadores comparten. Halperin, he argumentado anteriormente, afirma que en Argentina este modelo entra en crisis debido al statu quo político posterior a 1880. En contraste, en el estudio de la crisis de este modelo, Colmenares carga sus tintas en el discurso mismo, y encuentra las razones de la crisis en una incapacidad crónica de esta historiografia: la narrativa novelesca liberal de héroes y nación no era suficiente para explicar la multitud y la complejidad de los acontecimientos. En suma, carecían, diría Colmenares, de una teoría compleja y abarcante del curso que sigue la historia. Cuestión de enfoques: la realidad que rebasa los modelos (Halperin), los modelos que le quedan chicos a la realidad (Colmenares).

33 Colmenares, Las convenciones, p. 70.

34 lbid., p. 134. 
López, sin embargo, sostiene la necesidad de tener una teoría específica del desarrollo de la historia. Por ejemplo, este autor reclama a Mitre su falta de "una teoría de la revolución". Es más, le acusa de haber plagiado su teoría de la revolución. Sin embargo, para Colmenares la historiografia liberal del siglo XIX, no obstante sus pretensiones, no formula hipótesis ni teorias explicativas, sino que a partir de explicaciones de "orden psicológico o moral" o de metáforas que casi siempre, como en Mitre, tienen que ver con las ciencias naturales, trata de que la "trama oculta" que explica los hechos "[aparezca] a la vista, en la superficie del discurso, pero disimulada por su obviedad misma". ${ }^{35}$ Así, "el uso de los documentos estaba concebido en función de alguna idea general, y generalmente grandiosa, antes que en la banal reconstrucción de un hecho". ${ }^{36}$

Colmenares no se equivoca: entre el mar de datos y de tensión dramática, Mitre da a su discurso una lógica metafórica basada en los términos de la ciencias naturales; inútil buscar una concepción clara del orden y curso de la historia, pero a golpe de ocurrentes parangones biológicos o mecánicos, lo desconocido aparece como obvio. Por ejemplo, Mitre afirma en la Historia de Belgrano: "España pudo y debió ser la nación más poderosa y más próspera de la tierra, al haber permitido que se cumplieran las leyes de la naturaleza, aún sin poner de su parte...no lo hizo así porque le faltaba el instinto de la propia conservación...a un absurdo sistemático,

"S Colmenares, Las conuenciones, p. 177.

36 lbid., p. 133. que refluía principalmente en daño propio, no puede negarse la inconsciente buena fe. ${ }^{37}$

Como se ve, a la parodia naturalista, hay que agregar, en Mitre tanto como en López, el omnipresente apego al juicio moral de los hechos históricos. En efecto, el origen y el resultado del debate MitreLópez conlleva ciertas limitaciones políticas de la época (Halperin), pero también una incapacidad de contener el objeto histórico que se trata de reproducir (Colmenares). La prosa histórica del siglo XIX hispanoamericano dependía, dice Colmenares, "de su capacidad mimética y de ciertas convenciones dramáticas". El romanticismo europeo fue más rico y contó con varias formas de expresión, y modelos ad boc a sus circunstancias. El latinoamericano nació tísico. Lo explica Colmenares:

En Europa, tal lenguaje [histórico] se había desarrollado paralelamente a otras formas de figuración: la novela, la pintura histórica... La historia no sólo prestaba de ellas imágenes y técnicas de representación, sino que se remitía a su contenido alegórico simbólico [...], y aquéllas reforzaban el contenido figurativo del discurso histórico. Las dificultades de la figuración americana nacían de la ausencia de modelos adecuados de discurso y de la pobreza de otras formas de representación, literarias o pictóricas. ${ }^{38}$

El peruano R. Palma con su género de "las tradiciones" sobresalió en lo que Colmenares llamaría la otra forma no puramente histórica pero fracasada, de figuración de la realidad la cual existió

${ }^{37}$ Mitre, Historia de Belgrano, t. 1, p. 28.

${ }^{38}$ Colmenares, Las contenciones, p. 201. Cursivas nuestras. 
en Hispanoamérica durante el siglo XIX. ${ }^{39}$ Como Palma, en la Argentina Pastor S. Obligado y Bernardo Frías, o en México Heriberto Frías y Luis Gónzalez Obregón, intentaron reflejar, a la manera de un espejo, la realidad latinoamericana del siglo XIX. De eso, tiene razón Colmenares, Mitre no pudo pedir prestado nada. Y no porque, como piensa Colmenares, el costumbrismo de "las tradiciones" "tendía a identificaciones aisladas" que petrificaban la realidad en personajes o prototipos, sino porque "las tradiciones", decía Palma, deben tener "algo, y aun algos, de mentira, y tal cual dosis de verdad", y eso no iba con el deseo erudito de Mitre, ni con el subjetivista, pero al fin y al cabo bistórico de López. Acaso el supuesto éxito historiográfico de los historiadores del siglo XIX europeo, se debió más que a la facilidad de recurrir a otras formas de representación, precisamente al hecho de narrar no un fracaso sino el éxito tenido en tanto naciones imperiales, como la France de Michelet.

La metáfora fue, pues, el recurso de los historiadores como Mitre. Y esto no es sólo un descubrimiento de los estudios contemporáneos del discurso (Colmenares). Los propios contemporáneos de Mitre notaron su afán metafórico. Alberdi criticaba a Mitre por ser un historiador de los que creen que "cuando han encontrado una metáfora, una comparación, creen que han encontrado una idea, una verdad ${ }^{n} .^{40}$ En realidad el afán

${ }^{39}$ Véase Emilio Carilla, El romanticismo en la América bispánica, Gredos, Madrid, $3^{2}$ ed., 1975.

40 Alberdi, Escritos póstumos, Buenos Aires, 1897, t. v, p. 192. por la metáfora y la retórica, como veremos, responde a la posición del autor en su tiempo histórico: el romanticismo liberal y erudito de Mitre, como sugiere Colmenares para el caso de Andrés Bello, había sabido amalgamar la narración descriptiva y el "comentario filosófico" o de opinión. ${ }^{41}$

Colmenares, apoyado en las teorías sobre el discurso propias de la postmodernité nos revela tejidos secretos de quienes se empeñaban en la sola labor de ser prístinamente modernos. ${ }^{42}$

\section{III}

Nada de falso hay en lo que el maestro Tulio Halperin afirmara en las conferencias en homenaje al centenario de Sarmiento: la ventaja de la historia intelectual es que siempre encuentra lo que busca. El análisis histórico del pensamiento historiográfico, sin embargo, ofrece un campo privilegiado para intentar escapar al uso de esas "ventajas" que señalara Halperin; salir de los límites de aproximaciones ya más o menos establecidas; esto es, de formas relativamente puras de historia de las ideas, sociología de los intelectuales, historia política o análisis discursivo. Para no convertir

1 Véase Colmenares, op. cit., pp. 65-70.

42 De hecho, Halperin también había sugerido esta incapacidad, aunque no la colocaba en el centro de la crisis del modelo de Mitre como paradigma de la historiografia argentina: "La obra de Mitre ofrece en efecto un ejemplo particularmente exitoso de historiografia liberal-nacionalista... Pero es cada vez más evidente que hay sectores enteros de realidad histórica... que se integran mal en ese modelo historiográfico", Halperin, la bistoriografia..., p. 834 . 

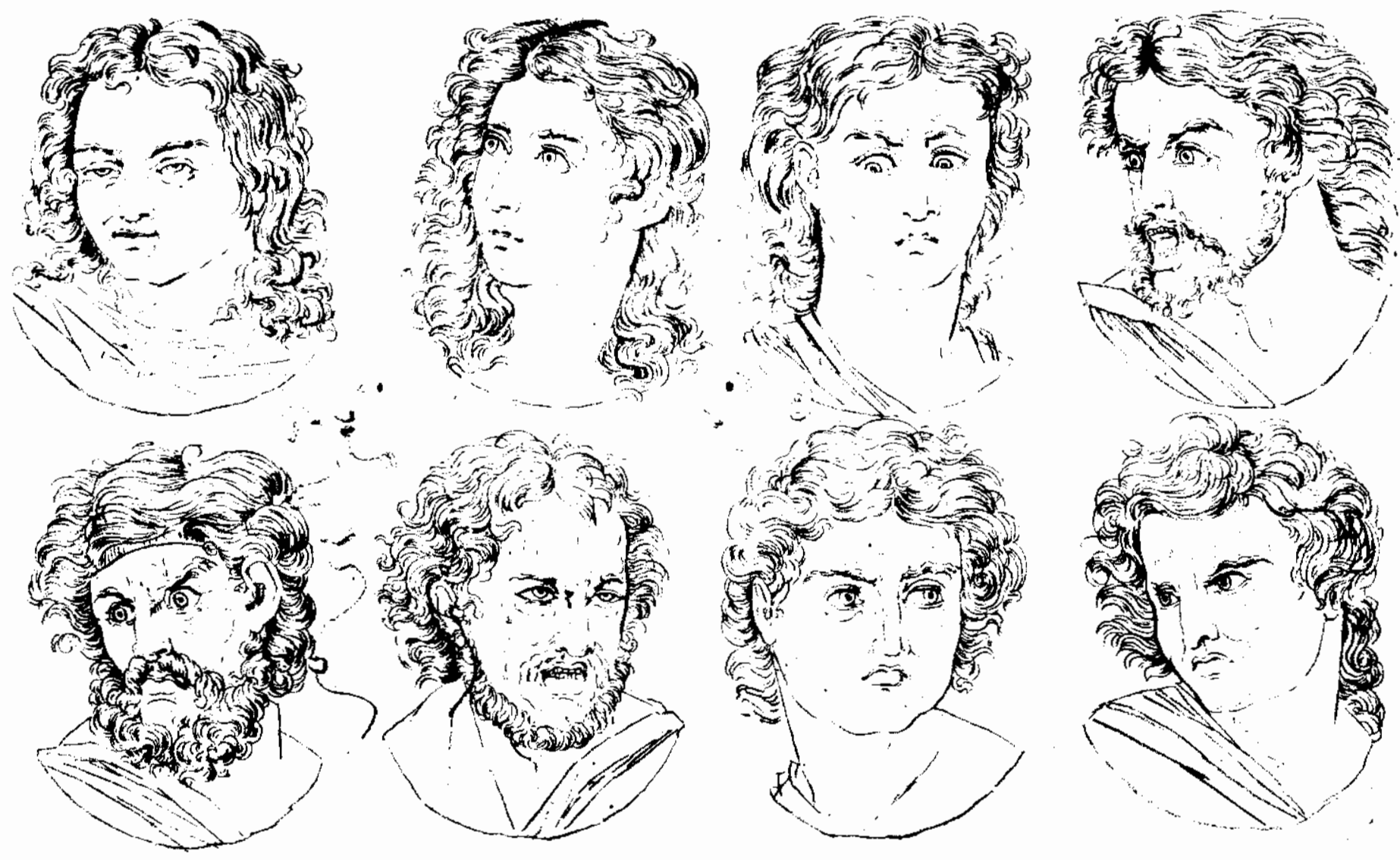

esto en un índice de autores y tendencias, baste decir que el estudio de lo cultural simbólico ideológico, por querer decirlo sin errar, ha mostrado varios excesos que van desde el determinismo empiricista (el cual supuestamente captura la evidencia de lo cultural, captura que es como jaula vacía que expone al aire, innegablemente una evidencia, como la presa), hasta los relativismos textualizantes para los que nada es verdad ni nada es mentira todo es según la estrategia discursiva con que se escriba.

Los debates de historiografia, como momentos historiables, tienen elementos políticos, sociales y narrativos vivamente explícitos que pueden, al ser analizados, hacer coincidir distintas aproximaciones. Por ello, en el análisis que nos concierne se puede encontrar una continuidad explicativa que recorre sin trabajo distintas aproximaciones a la historia de lo cultural simbólico ideológico. Así, el debate Mitre-López, propongo, es históricamente entendible, revelador, en tres planos entrelazados: a) el plano de la sociabilidad política e intelectual (comúnmente dominio de la historia política tradicional y/o de la sociología de los intelectuales); b) el plano de lo propiamente discursivo (terreno de los hoy en boga metahistoriadores, deconstruccionistas y demás) y c) el plano de las condiciones socioeconómicas en que se da una discusión historiográfica (contextualistas). Al explicar el debate Mitre-López es posible recorrer los tres planos con relativa solvencia y naturalidad, lo cual hace pensar que este tipo de guía meto- 
dológica -no obstante su riguroso eclecticismo- puede proporcionar al menos eso: un camino expedito de análisis.

\section{El tiempo y sus actores}

La mutua vivencia temporal y especial de quienes hacen y escriben historia produce líneas de pensamiento (armónicas y disonantes) que obtienen especial claridad de expresión en los debates intelectuales como el sostenido entre Bartolomé Mitre y Vicente Fidel López . Durante la segunda parte del siglo XIX el antiguo régimen ya había sido si no derrotado de facto en la esfera social y económica, sí desacreditado por completo como "aspiración" político-social. La inteligencia latinoamericana entonces adoptó la conciencia liberal en sus distintas versiones. No fue esto, como bien arguye Hale, un simple proceso de imitación de modelos europeos, sino uno de transformación de una ideología europea en un unifying myth. Un proceso llevado a cabo por las elites latinoamericanas, ${ }^{43}$ acaso en contra de la propia realidad social y económica de los pueblos latinoamericanos. En efecto, el siglo XIX no vio el acabarse de las estructuras económicas y sociales tradicionales, sí observó su descrédito.

Es dentro de esto que Hale llama ideological consensus que debe entenderse el debate Mitre-López. La historia de las ideas, tan querida de la historiografia tradicional, nos narra las mutuas y

49 Véase Ch. Hale, op. cit., p. 369.

14 Véase especialmente R. Levene, Las ideas bistóricas de Mitre, J. L. Robinson, Bartolomé Mitre, University Press of America, 1982; José Luis Romero, Argentina, imágenes y perspectivas. variadas lecturas e interpretaciones de la literatura europea a que Mitre y López estuvieron expuestos. ${ }^{44}$ Mitre es el autodidacta, cuya lectura más preciada -él lo confesó fue Tocqueville; López es el discípulo de Diego Alcorta, sus lecturas van desde Guizot, Michelet, Saint-Simon, a Voltaire, Carlyle, Buckle, Thiers y Taine. En verdad, no hay grandes diferencias entre las lecturas de Mitre y las de López; ambos comparten la misma sociabilité intelectual. Liberalismo y romanticismo son los conceptos que seguramente abarcan las ideas y tendencias expresadas en ambos autores.

Para llegar a este consenso ideológico, no obstante las discrepancias en el cómo escribir la historia, ayudó la convivencia generacional y la experiencia vivencial común de los intelectuales de Buenos Aires (incluyendo su exilio). José Ingenieros trazó la ruta de la generación de Mitre y López, de aquel café literario de Juan María Gutiérrez, J. B. Bautista, V. F. López y E. Echeverría, al surgimiento del grupo Joven Argentina (1837), a la creación de publicaciones ( $L a$ Moda, El progreso), al exilio durante el rosismo (López sale exiliado en 1840 a Chile, donde crea el salón literario de Chile, 1842, y Mitre a Montevideo). En fin, un camino conjunto de lecturas, discusiones, pleitos, versos, bohemia y, muy importante, logias y participación política. ${ }^{45}$

Dentro del consenso liberal, empero, florecieron distintas posiciones y contradicciones, derivadas, por una parte, de la naturaleza misma del discurso histórico que se escribía (problemas

$45 \mathrm{~J}$. Ingenieros, "La evolución de las ideas argentinas", Obras completas, vol. 13, t. 5, Buenos Aires, 1957. 
propios de los autores del tiempo bistórico). Por otra parte, de las condiciones intelectuales y sociales (que hacen posible debates como el de Mitre y López), así como de las intenciones personales de cada uno de los historiadores (con el afán muy suyo de estar a thempo).

\section{Los autores del tiempo}

En el plano del discurso histórico, el debate Mitre-López expresa nítidamente las creencias y contradicciones del consenso (que no acuerdo) ${ }^{46}$ romántico liberal prevaleciente en el siglo XIX (en especial en su peculiar versión argentina). En este sentido, dos paradojas fundamentales son señalables dentro de este consenso, ambas producto del afán de crear lo que Halperin llama la historia de la nacionalidad argentina, o la que Colmenares denomina la "comunidad imaginada". La primera se sintetiza en la obsesión intelectual y política por lo europeo liberal vis-à-vis la realidad histórica y política de la Argentina del siglo XIX. La otra paradoja está constituida por dos voluntades encontradas: voluntad de verdad $u s$. la del estilo.

Tanto para Mitre como para López (como tal vez para cualquier historiador, cualquier historia), darle historia a una nación es una tarea artística y científica. Requiere de investigación, de ideas imaginativas relativamente claras del curso del presente y del futuro, e inevitablemente contiene intereses de poder.

\footnotetext{
16 Para una exposición de las distintas divisiones del liberalismo argentino entre 1846-1880, véase Halperìn, "Prólogo".
}

Para 1835 Argentina experimentaba la dictadura de Rosas que por sí sola se traducía en el triunfo de la "barbarie" sobre la "civilización". Sin embargo, al mismo tiempo significaba el logro de la estabilidad política, especialmente añorable después del caos bélico. Durante el rosismo, Mitre y López salen al exilio, su idea de nación incumplida. Tanto para Mitre como para López, el módelo de nación es la república democrática, modelo que había sido proporcionado a las elites latinoamericanas por la ilustración y la revolución francesa, no sólo para su uso en la arena política sino en el de la escritura de la historia: "Los modelos narrativos de la revolución francesa imponían patrones de interpretación a la luz de una trama y un inventario reconocible de actores históricos. ${ }^{\text {177 }}$

Ante este dilema entre liberalismo como "paradigma" (como ambas cosas: anhelo, e instrumento de interpretación), López favorece el relativismo militante: escribir los momentos épicos, los sentimientos, la emoción de una nación liberal de acuerdo a su propia posición liberal en la época que le ha tocado vivir:

La historia es siempre obra de partido, porque el que la escribe es siempre un hombre que tiene una intención, un interés. Aun aquel que se arma de toda la imparcialidad que cabe en el alma de un escritor de elevado y honrado carácter, tiene que juzgar cuando escribe de una lucha, de un pleito...y desde luego tiene que juzgar por sí propio, como un juez, con sus opiniones y con sus convicciones. Pero, como todos estos elementos de juicio son movibles...no llegará a otra cosa que a decir lo que él opina de los sucesos

${ }^{47}$ Colmenares, op. cit, p. 28. 
que narra...y el criterio histórico estará siempre en la historia del pasado como el pasado mismo lo estuvo en la lucha de los hechos y en la manera de apreciarlos, cuando este pasado era presente. ${ }^{48}$

Bartolomé Mitre, mucho más complejo y, como sugiere Halperin, con una mira mucho más amplia que la de López, responde con dos armas a esta paradoja entre "paradigma" liberal y realidad nacional. A saber, el recurso a los excepcionalismos tocquevilleanos de la teoría liberal, y al original heroísmo criollo. La Historia de Belgrano despliega su respuesta a esta paradoja y sus recursos: la vida del héroe criollo, con su arrojo, su conocimiento y dominio de la barbarie (la cual sólo el criollo puede tener); y la historia del surgimiento de la democracia "orgánica": la nación. Nación cuyo destino "natural" es la república y esa democracia "orgánica", pero cuyo camino es accidentadamente excepcional (frente a los modelos europeos clásicos). Mitre tenía que llevar a cabo la reivindicación, "tan parecida a invención" (como diría Halperin) de la historia. Primero, para el partido, luego para la nación. Dice Mitre en la Introducción de la Historia de Belgrano:

Este libro es al mismo tiempo la vida de un hombre y la historia de una época. Su argumento es el desarrollo gradual de la idea de la independencia del pueblo argentino desde sus origenes a fines del siglo xvin y durante su revolución, hasta la descomposición del régimen colonial en 1820 , en que se inaugura una democracia genial, embrionaria y anárquica que tiende a normalizarse dentro de sus propios elementos orgánicos. ${ }^{49}$

4" López, Debate bistórico, t.III, p. 70.

19 Mitre, Historia de Belgrano, p. 2.
Esa "democracia genial" tuvo su excepcionalismo como el de La democracia en América, incluyó la lucha contra the wilderness y su excepcional desempeño: "Así nació y creció la colonización argentina en medio del hambre y la miseria, pidiendo a la madre tierra su sustento, y se fortaleció en medio de dolorosos sufrimientos, apresada en Sudamérica el único ejemplo de una sociabilidad hija del trabajo reproductor. ${ }^{n 50} \mathrm{E}$ igualdad natural sin paralelo en las naciones que contaron con un sólido antiguo régimen: "...como en realidad no había pobres ni ricos, siendo todos más o menos pobres, resultaba de todo esto una especie de igualdad o equilibrio social, que entrañaba desde muy temprano los gérmenes de una sociabilidad libre, en el sentido de la espontaneidad humana". 51

A ojos de la historiografía contemporánea, lo que explica la sociedad y el curso de la historia en Mitre puede resultar demasiado limitante, acartonado. En realidad, ha sido dicho antes, Mitre no parece haber contado, más allá de su modelo de evolución hacia la nación democrática republicana, con una noción más compleja del curso que podría tomar la historia (en verdad, noes posible que tuviera tal noción). Aunque no exista tal noción, sí hay en Mitre las metáforas mecánicas e ingeniosas que Colmenares señalara; hay la exitosa transformación de las ideas liberales en unifying myth (Hale). Sin embargo, la conciencia, quiero decir, el sueño del liberalismo se enfrenta siempre a su anatema que es la

\footnotetext{
${ }^{50}$ Mitre, Historia de Belgrano, t. I, p. 9.

"I Ibid., p. 11
} 
- "barbarie" argentina, o la consolidación de una democracia ficción. Con todo, no obstante lo limitante que parezca su visión, para Mitre el origen de la historia argentina, la independencia, es perfectamente abarcable desde su perspectiva.

La revolución de independencia, por ello, se volvió el tema común para los historiadores hispanoamericanos. El modelo que la revolución francesa había proporcionado y el "espíritu romántico"52 de discurso en que se encontraban sumergidos los historiadores como Mitre y López, además de la cercanía misma del surgimiento de los nuevos estadosnaciones, hicieron inevitable esta elección de las revoluciones de independencia como tema central. Como sostiene Colmenares, en tanto que en Europa la burguesía pudo "universalizar sus pretensiones" y juntar en una línea evolutiva su pasado y su presente, el criollo hispanoamericano "sentía que tenía que partir de cero...Su identidad se había forjado en y por la revolución...Sólo a partir de la revolución, un acontecimiento originario en todo sentido, podía reconstruirse la totalidad de la historia, hacia atrás y hacia adelante. ${ }^{53} \mathrm{El}$

\footnotetext{
32 Para una explicación de los contenidos de este espiritu romántico, tanto en historiografia como en literatura, vease H. G. Schenk, The mind of the european romantics. An essay in cultural bistory, Londres, 1966 (utilizo la traducción castellana, El espiritu de los románticos europeos, $\mathrm{FCE}$, México, 1983). En esencia, este espiritu romántico incluía dos características fundamentales: la especial necesidad de rescatar el pasado (nostalgia), y la crítica o insatisfacción con el presente desde el cual se habla. Tal crítica o insatisfacción puede resolverse en un proyecto de futuro mejor $o$, como en el caso de Mitre (mezclado con ideas de evolucionistas y liberales), en la seguridad de estar en un estado incompleto de evolución que el futuro verá exitosamente terminado.

"3 Colmenares, op. cit., pp. 95-96.
}

pensamiento historiográfico del siglo XIX, pues, es en mucho no una idea general de la historia, sino el pensamiento sobre lo que fueron las luchas de independencia, y, lo más importante, sus detalles.

Un derivado de esta paradoja entre conciencia liberal y realidad argentina es el dilema a que se enfrentan los historiadores que toman (Mitre y López) como leitmotiv la revolución de independencia; dilema entre escribir la simple historia del heroísmo de la revolución, o escribir -al menos proponer- el total curso "objetivo" de la historia patria. Lo primero significaría lograr el momento de máxima expresión del, decía Hegel, "espíritu de un pueblo"; es decir, conseguir esfumar toda individualidad entre una comunidad cuya mejor voz sería la épica de su revolución. Por otra parte, proponer una idea total de historia patria significaría intentar la "objetividad científica"; narrar el pasado como "pasó" y proporcionar el mapa general del desarrollo de la nación, pero manteniendo la individualidad tanto del autor de la historia, como de los actores históricos ${ }^{54}$ proponiendo héroes, que por "reales", pudieran ser compartidos por todas las facciones. Así, en esta segunda opción, se ponía en riesgo la narración liberalromántica guiada por la línea progresiva hacia el logro de la nación (por liberal), pero también heroica y epopéyica (por romántica). López definitivamente opta

${ }^{34}$ Botana resume este dilema en un encuentro entre publicistas e historiadores (entre Mignet y Tocqueville): "Por un lado, la necesidad de la historia que colocaba a la revolución en el umbral de un nuevo tiempo; por otro, la autonomía individual que podia orientar esa tendencia hacia el bien de la libertad o hacia el mal del despotismo", N. Botana, Mitre y la bistoria de la libertad. 


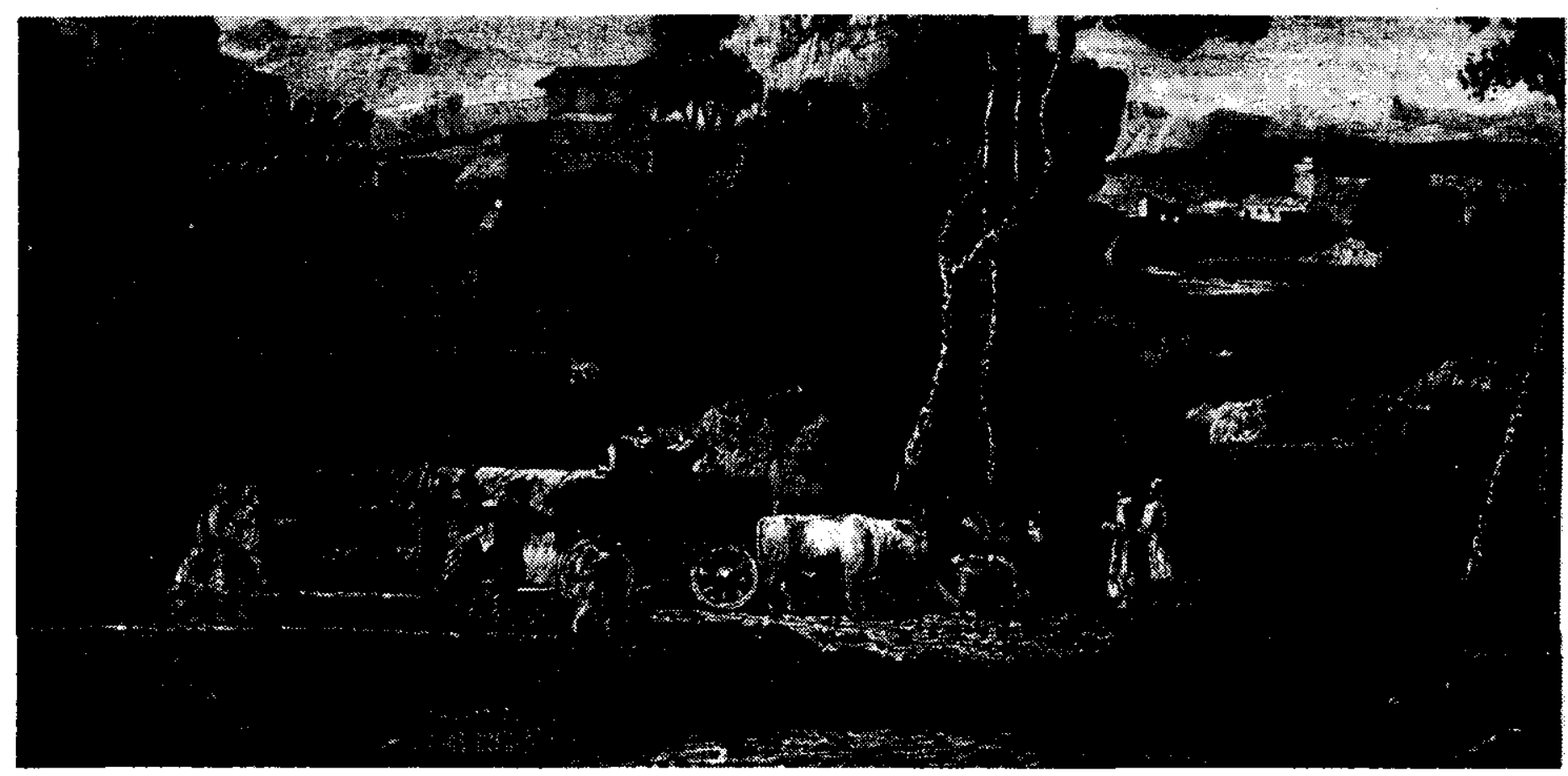

por lo primero; Mitre apuesta, sin éxito completo, a lo segundo.

Este relativo éxito de Mitre puede ser observado en el elemento más sonoro del debate Mitre-López, a saber, la discusión sobre el uso de las evidencias empíricas. Generalmente, el uso de estas evidencias se equipara con la historia de tipo científico, positivo. Empero, positivismo y liberalismo no nacieron juntos.

El positivismo, en Latinoamérica, es un agregado de la última parte del siglo XIX a la ideología liberal. En cierto modo, fue también un instrumento para responder al dilema anteriormente explicado. Una historia positiva, erudita y neutral daría por resultado el logro de una historia patria, ipor fin!, completa y "exacta". Mitre aparentemente presenta estas tendencias positivistas, en tanto López descara su opción: construcción de una historia ad boc con la conciencia $\mathrm{e}$ intereses del presente, su presente.

Desde lejos, hoy, Mitre y López parecen estar en igual bando. De hecho, ya Alberdi colncaba a Mitre del mismo lado que López: Mitre "habla por figuras y símbolos, aunque hable de las cosas más prosaicas; tal vez por vocación poética...Sus disertaciones históricas sobre la revolución son titirimundis, no discursos...los sentidos se entretienen con su lectura, el espíritu muere de hambre...[los trabajos de Mitre] embriagan pero no nutren"..$^{55}$ Vistos a lo lejos, los trabajos de Mitre, no hay duda, tuvieron más trascendencia historiográfica. Ello no significa que entonces hubiese triunfado la historia científica, sino sólo que Mitre fue mejor detective, mejor promotor $y$, veremos, mejor escritor...Que la república posible a la manera de Mitre, fue la mejor pesquisa, la más ilustradora de su tiempo.

Como los románticos europeos, los historiadores liberal-románticos latinoamericanos del siglo XIX, ponen un fuerte acento en la técnica literaria, porque, como sostiene Levin de los historiadores románticos norteamericanos, "no solamente porque habian sido hombres de letras antes de volverse historiadores,

"Alberdi, Escritos póstumos, Buenos Aires, 1897, t. v, p. 193. 
. sino también porque creían que la recreación del pasado requería de habilidades imaginativas y literarias ${ }^{n}{ }^{56}$ Este apego provocó inevitablemente un encuentro entre esta voluntad de estilo, y la no menos fuerte voluntad de verdad que, por ejemplo, Mitre enfáticamente señalaba. Detrás de cada hecho o dato, en Mitre o en López, está la búsqueda del momento estético-literario, expresado a la manera del ambiente intelectual de su época: tiempos de elocuencia, tiempos, a su manera, barrocos. ${ }^{57}$ Porque la historia no sólo debe decir la verdad, debe hacerlo bellamente para ser creíble. Si la verdad es accesible independientemente al discurso y a la voluntad del historiador, entonces no siempre puede ser compatible con la belleza. No pocas veces se habrá enfrentado Mitre a optar entre la verdad o la belleza; sus contradictorias respuestas, como sostiene Halperin, lo hacen más rico. López nunca dudó: quería la belleza de estilo en la historia, porque había que crear conciencia, convencer. El Mitre joven creía que los argentinos ignoraban su historia, y que la novela haría popular "nuestra" historia, pues la novela es la única capaz de presentar la "realidad llena de colo-

56 D. Levin, History as romantic art, Bancroft, Prescott, Motley and Parkman, Stanford, 1959, p. 9. También Lopez y Mitre fueron novelistas antes que historiadores; recuérdese la novela de López La novia del bereje o la inquisición de Lima (1854), y las de Mitre, Soledad (1854) y El botón de la rasa (1854). Mitre, además, hizo sus incursiones en poesia, imitando, como sostiene Kom, a Espronceda y Lamartine, A. Korn, El pensamiento angentino, Buenos Aires, 1962.

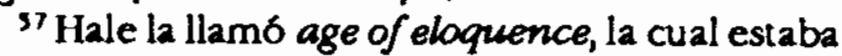
marcada, al menos en México, por la influencia del orador español Emilio Castelar, Hale, op. cit., pp. 368-377. rido y movimiento".$^{58}$ Lopez , por su parte, copiaba a Walter Scott en su novela La novia del berejey defendia el carácter literario de la historia; lo ejercía, por ejemplo, en la introducción a la Historia de la revolución argentina: "Cada uno abrazó y colmó de besos su fusil, y durante todas esas noches los grupos se concentraron a porfia en sus respectivos cuerpos, sin que nadie los arrastrase. ${ }^{\text {n99 }}$

Mitre maduro reniega del carácter literario de la historia, pero, se ha dicho ya en este trabajo, no desprecia oportunidad de desplegar su capacidad literaria, su estilo "Luis Felipe", como lo llamó Korn. Un ejemplo:

El reloj del cabildo daba las 12 de la noche al tiempo de terminarse la votación. Aquella fue la última hora de la dominación española en el Río de la Plata. La compañía que debía tocar más adelante las alarmas de la revolución, resonaba en aquel momento lenta y pausada sobre la cabeza de la primera asamblea popular que inauguró la libertad y proclamó los derechos del hombre en la patria de los argentinos. ${ }^{60}$

El historiador hispanoamericano romántico que no tuvo opción (tuvo que tomar la nación y su independencia por tema) enfrenta, pues, la paradoja inherente a su tipo de narración. En otras palabras, a la vez que intenta narrar la verdad, la pinta (estéticamente) y le da el tono de drama. Esta paradoja se desbalan-

58 Mitre, Soledad, pp. 94-95, citado por Burns, Bartolomé Mitre, p. 159.

"Citado por Lopez en Debate bistórico, t. II, p. 77.

${ }^{60}$ Mitre, Historia de Belgrano, t. I, p. 327. 
cea con el arremeter del positivismo, en la última parte del siglo XIX. Desde la posición del positivista, la verdad científica se vuelve claramente obtenible y definible, por lo cual el momento estético pierde prestigio. Aunque Mitre y López dan muestras de estas dos voluntades (verdad y estilo), es evidente que el extremo literarioy subjetivista está representado por López. Pero Mitre sabía que en historia patria, como decía un liberal mexicano de la política, "la forma es fondo". Paradoja de la paradoja: aquí Mitre también venció pero perdió: fue indiscutiblemente mejor historiador que López, pero porque fue mejor escritor y mejor estilista que López .

Mitre y López, pues, no proponían maneras radicalmente distintas de elaborar una narrativa histórica. Empero, corrieron distinta suerte dentro de las paradojas que ambos enfrentaron en el "oficio de historiador". Si sus discursos tienen más en común de lo que se cree, el hecho mismo de discutir explica más sobre estas similitudes las cuales son, en efecto, el meollo de la historiografia latinoamericana del siglo XIX.

\section{Los autores a tiempo}

Otra dimensión posee el debate MitreLópez, la más mundana. Se trata no del debate, sino del hecho mismo de debatir. ¿Por qué se da este debate en la Argentina del siglo XIX? ¿Por qué en Chile, primero, y luego en Argentina existe el debatir en el nivel que alcanzó la discusión entre Mitre y López? ¿Qué permite en lo socioeconómico, qué impulsa en lo personal, un debate como el sostenido por Mitre y López?
Para debatir como ellos se requería haber alcanzado el consenso liberalromántico (que hiciera imperativo escribir la historia, al mismo tiempo que posibles las posiciones metodológicas y estilísticas distintas), pero sin la consolidación completa de un consenso positivista (que habría evitado cualquier debate, pues el positivismo en sí contiene una idea sólida del cómo se hace y cómo se desarrolla la historia). ${ }^{61} \mathrm{La}$ oposición entre conservadores, hispanistas $y$ monárquicos, y liberales francófilos y republicanos, en Argentina y Chile, pronto (1820) se desvaneció en discusiones abarcadas por el consenso más o menos republicano y liberal. No debe olvidarse que para 1880 Mitre y López son historiadores maduros cuyas ideas y creencias habían sido adquiridas y expresadas ya a mediados del siglo XIX. A partir de la caída de Rosas en 1852, sin duda Félix Frías primero, y posteriormente Estrada constituyeron opciones argentinas francamente conservadoras. Sin embargo, como arguye Halperin, Frías estaba "muy consciente de que escribía para países que la providencia había destinado a ser republicanos" ${ }^{62} \mathrm{En}$ efecto, ni las opciones reaccionarias fueron radicales, ni formaron parte del

${ }^{61}$ No que el pensamiento positivista no estuviera presente antes en Argentina (de hecho Mitre es influido por éste), pero en verdad no se ha vuelto el pensamiento dominante que a finales de siglo acabaría siendo. Kom barrocamente explicó así la llegada del positivismo a Buenos Aires: "Aún cruzaban por la escena los reyes románticos en todos los oropeles del verbo huganiano, pero el rey verdadero, de chistera y con paraguas, se codeaba en las aceras con los otros burgueses", Korn, op. cit., p. 163.

${ }^{62}$ Halperin, "Prólogo", p. xovy. 
.corazón de la discusión política o historiográfica. Argentina no contó con un Lucas Alamán. ${ }^{63}$

En tanto para mediados de siglo las disputas entre conservadores, monárquicos hispanistas, y liberales republicanos existían en lo que fuera el corazón del imperio español (México y Lima), en lo que fue la periferia (Argentina y Chile) se obtiene más rápidamente $\mathrm{y}$, sobre todo, más homogéneamente, un consenso liberal. En México y en Lima, eran muy fuertes los vínculos con el antiguo régimen, y era alto el número de población indígena, la cual tradicionalmente se encontraba profundamente ligada a la labor cristianizadora de la Iglesia y, por tanto, a la corona española. En el otro lado, la originalidad del desarrollo político-intelectual de Argentina. Esto es, se podría concordar con Halperin en que los liberales argentinos fueron únicos dentro del contexto hispanoamericano, porque muy agudamente previeron la nación argentina. Sólo el progreso argentino, arguye Halperin, "es la encarnación en el cuerpo de la nación de lo que comenzó por ser un proyecto formulado en los escritos de algunos argentinos cuya única arma política era su superior clarividencia". ${ }^{64}$ Esta "superior clarividencia" no sólo es hija de la perspicacia intelectual de los liberales argentinos, sino de una más clara conciencia de los intereses de clase de la elite argentina

${ }^{63}$ Al respecto consúltense los ensayos contenidos en El espejo de la bistoria. Problemas argentinos $y$ perspectiuas latinoamericanas de Tulio Halperin, Buenos Aires, Sudamericana, 1987; especialmente véase la interesante comparación entre los liberalismos argentino y mexicano.

"Halperin, "Prólogo", p. III. que entonces veía crecer su poderio económico por su auge exportador.

Riman con sus más claramente definidos intereses de grupo, sus sutiles intenciones personales. La tentación de trascendencia para los historiadores hispanoamericanos del siglo xIx fue mayor que la de cualquier historiador "profesional" contemporáneo. Para los historiadores románticos hispanoamericanos, como Mitre y López, dejar huella de que ellos participaron en la construcción de la nación era tan vital como para el ensayista francés romántico De Senacour quien tuvo el anhelo de infinito, de suyo romántico, "eternité, deviens mon asile", dejó escrito en su tumba. Es esta la otra razón que yace tras del verbo debatir.

Historiográficamente, López quiere la fama de su tiempo; interpretar es entender, y él quiere presentar la mejor interpretación, la más bella y digerible para su época. Que las otras épocas, parece sugerir, se hagan de su propia interpretación, negando o afirmando la suya. Mitre, se sabe una piedra en el camino progresivo hacia el logro de la historia nacional, porque su riqueza está en los datos. Mitre termina la segunda parte de sus Comprobaciones:

Así de algún provecho habrá sido la discusión que dio origen a estas Comprobaciones. Si después de olvidada la polémica sirviesen aún, según su título lo indica, para la comprobación de algunos hechos históricos que carecían de ella, podrá decirse de ellos lo que de otros libros de circunstancias que, merced a su utilidad relativa, más que por lo que son en sí, no mueren al día siguiente de nacer: babent sua fata libella, que hasta los pequeños libros tienen sus hados. ${ }^{65}$

${ }^{65}$ Mitre, Comprobaciones, p. 647. 
No que Mitre no quiera trascender como historiador, sino que Mitre sabe segura su trascendencia (presidente, historiador, novelista, héroe militar), tiene fe en su sueño del futuro de la república $y$ siente confianza en sus metáforas explicativas, en su estilo, en su forma "objetiva" de narrar la historia. Trascendencia que atestiguaron hasta odas de Darío. ${ }^{66}$ López , con su Debate bistórico confunde, ¿quiere que sea debate de historia? o ipretende que sea un debate bistórico? Sin duda ambas cosas, porque está consciente de la trascendencia que le da intercambiar puntos de vista con Mitre.

"No hay un acuerdo completo en lo sustancial de nuestros juicios?", así, reconciliatoriamente, Lópezescribía a Mitre en 1892. Y Mitre le contestaba que "lo que hemos disputado ha sido el modo de ponernos de acuerdo". Los dos coinciden en que deben ser ellos considerados "los más genuinos historiadores nacionales". ${ }^{67}$ En efecto, como le sucedie-

${ }^{66}$ Entre los versos de Oda a Mitre, Darío hacía héroe a Mitre, lo alababa quizá en contra del mismo Mitre (como en: "Y para mi, Maestro, tu vasta gloria es ésta: / amar los becbos fugaces de la bora, sobre la ciencia a ciegas, sobre la bistoria espesa/la etema poesía más clara que la aurora. "), pero daba sin duda muestras de la trascendencia de Mitre (como en: "GGloria a ti que, provecto como al destino plugo,/ la ancianidad tuviste más límpida y más bella;/ tu enorme catafalco fuera el de Victor Hugo,/ si hubiera en Buenos Aires un Arco de la Estrella!"), Rubén Dario, Canto a la Argentina. Oda a Mitre. Canto épico a las glorias de Cbile, Austral, Buenos Aires, 1949, pp. 85-106. Cursivas nuestras.

${ }^{67}$ Mitre, Correspondencia literaria, bistórica y politica, citado por Campobasi, José Mitre y su época, p. 453. ra al futuro de la nación, el final de la vida de ambos escritores no se parecía a la imagen esperada; se les hizo evidente que antes que la historia, podían existir varias historias del devenir argentino. Por lo cual, el debatir por los detalles de muy similares proyectos de narración histórica perdió uno de sus sentidos. Pero otro quedó vivo: Mitre y López sabían que el escribir y debatir sobre la historia los hacía, en su tiempo, partícipes de la construcción nacional y por supuesto historiadores. Y por ello, para el "postrero historiador", el de nuestro tiempo y el del porvenir, Mitre y López son también historiadores e historiables.

Bartolomé Mitre y Vicente Fidel López debatieron inmersos en un consenso liberal, preocupados por los detalles de una historia cuyo fin ideal ambos compartían. Debatieron recorriendo las paradojas y dilemas propios de su pensamiento (liberal-romántico) y de sus intereses políticos (la república, la nación soñada por la elite porteña) en su tiempo histórico. La suerte que corren ante las dos realidades, la argentina que no vieron o vieron a medias, y la que crearon en sus historias patrias, explica su debate. Sus problemas no empiezan y terminan en distintas concepciones del uso de datos, de maneras de reflejar la realidad de Argentina en el siglo XIX. En su debate se colaron los pormenores problemáticos, para ambos, del escribir sus historias destinadas a volverse "pasado nacional". En su debate, la certeza de las discrepancias habla de las dudas compartidas en aquello de narrar convincente, estéticamente y "con verdad" la historia nacional. 


\section{SECUENCIA}
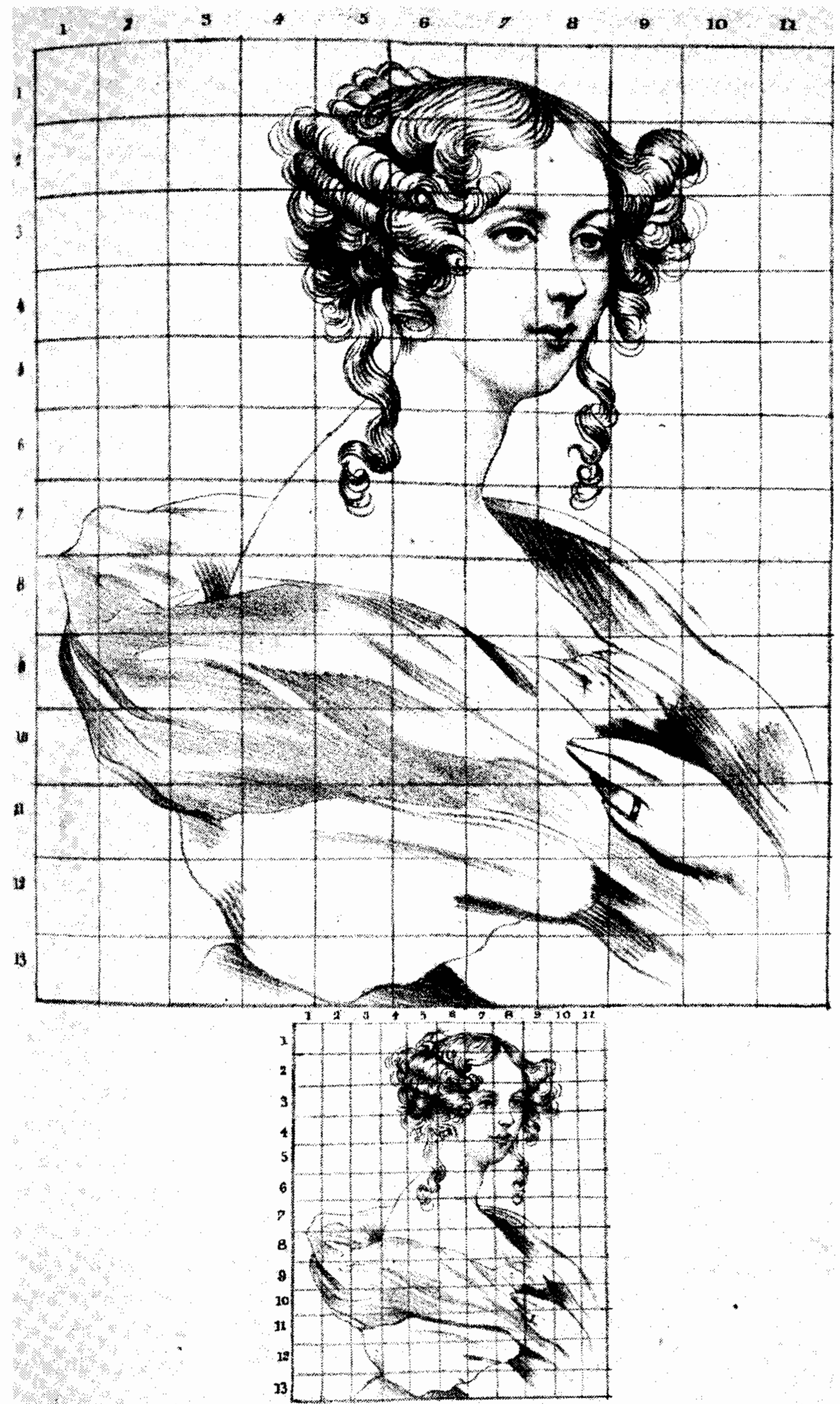